\title{
Effects of Chromium Supplementation on the Infrapopulations of Anacanthorus (Monogenoidea) and (Dinoflagellida) Parasites (Characidae) Piscinoodinium of Piaractus \\ penilabiatus pillulare mesopotamicus
}

Rodrigo Yudi Fujimoto*, Marcello Pardi de Castro, Maurício Laterça Martins, Flávio Ruas de Moraes, Jamille Elzira de Almeida Varella and Daniel Guerreiro Diniz

Universidade Federal do Pará; Campus Bragança; Rua Leandro Ribeiro, s/n; 68600-000; Bragança - PA - Brasil

\begin{abstract}
This study evaluated the parasitism by Anacanthorus penilabiatus (Monogenoidea) and Piscinoodinium pillulare (Dinoflagellida) in the gills of "pacu", Piaractus mesopotamicus supplemented with chromium in the diet. Randomised delineation by using factorial scheme (4x2x2) for Monogenoidea and $4 \times 2 \times 3$ for Dinoflagellate with four levels of chromium $(0,6,12,18 \mathrm{mg} / \mathrm{kg}$ diet $)$, two stocking densities $\left(4 \mathrm{~kg} / \mathrm{m}^{3}\right.$ and $\left.20 \mathrm{~kg} / \mathrm{m}^{3}\right)$, two classes of length (higher and lower than $17 \mathrm{~cm}$ ) for a period of 7, 60 and 90 days, and four replicates was used. The fishes in low density which received 12 and $18 \mathrm{mg} / \mathrm{kg}$ showed decreased monogeneoidea values, seven days after the experiment begin. Six, 12 and $18 \mathrm{mg} / \mathrm{kg}$ caused reduction in the dinoflagellate number in the fishes maintained at $20 \mathrm{~kg} / \mathrm{m}^{3}$. It was possible that chromium supplementation $(12$ e $18 \mathrm{mg} / \mathrm{kg}$ ) favoured the fishes health by reducing Monogenoidea and Dinoflagellida number in lower and higher densities, respectively.
\end{abstract}

Key words: Piaractus mesopotamicus, chromium, stocking density, Piscinoodinium pillulare, Anacanthorus penilabiatus

\section{INTRODUCTION}

New technologies in intensive fish culture and diets of good quality are essential as the development of aquaculture in Brazil. This system is responsible for chronic stress due to high stocking density as supported by Tort et al. (1996), Rotlland et al. (1997) and Montero et al. (1999). Stressors may provoke alterations in the host equilibrium affecting the health of fish. (Wedemeyer, 1997). Cortisol release is the most important response stress in the fish (Mazeaud and
Mazeaud, 1981; Camacho, 1999; Belo, 2002; Brum, 2003). Its elevated concentration reduces the defense response of the fish (Pickering and Pottinger, 1985; Maule et al., 1989; Belo, 2002; Brum, 2003) and results in increased susceptibility to parasitic and infeccious diseases (Barton and Iwama, 1991).

Vitamins and minerals are important in the physiological processes minimizing the effects of stressor agents. Hexavalent chromium is toxic but the trivalent form reduces the stress. The last one, improves the insulin action and reduces the

\footnotetext{
* Author for correspondence: ryfujim@pq.cnpq.br
} 
cortisol concentration in stressed animals (Anderson, 1994, Commitee on Animal Nutrition, 1997, Hasten et al., 1997, Hossain et al., 1998). Thus, the dietary supplementation with chromium may constitute an alternative to reduce the effects of parasitism in fish (Pickering and Pottinger, 1985).

Monogenoidea presents high host specificity as related by Rhode (1993) and Kritsky et al. (1997). Anacanthorus penilabiatus Boeger, Husak and Martins (1995) (Dactylogyridae: Anacanthorinae) parasite of "pacu" Piaractus mesopotamicus Holmberg, (1887), represent the main source of mortalities in the Northeast São Paulo (Martins et al., 2002). Elevated number of parasites indicates poor water quality, which favours the parasite reproduction (Thatcher and Brites-Neto, 1994; Noga, 1996) and induce stress in fish (Yadav and Akela, 1993; Alkahem, 1994). Moreover, the high stocking density causes food competition and lower utilization of dietary nutrients (Rotlland et al., 1997; Tort et al., 1996; Montero et al., 1999).

Low water quality and inadequate handling also favour the reproduction of dinoflagellate Piscinoodinium pillulare (Schäperclaus, 1954) (Lom, 1981) and high mortalities of fishes $(1,500$ fishes/day for 15 days) were found in São Paulo State (Martins et al., 2001).

Thus, the objective of this study was to evaluate the parasitological indexes of monogenoidea and dinoflagellate in the gills of $P$. mesopotamicus supplemented with trivalent chromium in diet during 90 days maintained in two different stocking densities.

\section{MATERIAL AND METHODS}

\section{Fish maintenance}

Piaractus mesopotamicus with averages of $100 \mathrm{~g}$ of weight and $20 \mathrm{~cm}$ of total length were acclimatized for 10 days in 32 aquaria of 5001 capacity, provided with dechlorinated water 1 1. $\mathrm{min}^{-1}$. Fishes were fed ad-libitum with dry ration, twice a day. After this period the animals were redistributed in two stocking densities, 4 and 20 $\mathrm{kg} / \mathrm{m}^{3}$, as suggested by Rotlland et al. (1997) and fed for 90 days.

\section{Experimental trials}

The monogenoidea experiment was constituted by 16 treatments, using factorial scheme $4 \times 2 \times 2$ wtih four levels of dietary chromium $(0,6,12,18 \mathrm{mg}$
CQC/kg diet), two stocking densities (4 and 20 $\mathrm{kg} / \mathrm{m}^{3}$ ), two classes of length (higher and lower than $17 \mathrm{~cm}$ ) with four replicates. The dinoflagellate experiment was designed with 24 treatments in factorial scheme $4 \times 2 \times 3$ with the same four levels of chromium and stocking densities, and three periods of evaluation (7, 60 and 90 days) also with four replicates.

\section{Diet, feeding and handling}

The diet was composed by fish meal (13\%), soy bean meal (23\%), wheat meal (21\%), crushed corn $(25 \%)$, rice meal $(16 \%)$, soy oil $(1 \%)$, mineral and vitamin supplement $(1 \%)$ with crude protein $26 \%$, ether extract $6.23 \%$, crude fibre $6.25 \%$, crude energy 3,900 $\mathrm{kcal} / \mathrm{kg}$ diet and relation calcium/phosphorus 1.45:1. Composition of mineral and vitamin supplement without chromium (nutrient $/ \mathrm{Kg}$ ) was according to A.O.A.C. (1984) as follows: iron $15,000 \mathrm{mg}$, cooper $5,000 \mathrm{mg}$, iodine $500 \mathrm{mg}$, manganese $17,000 \mathrm{mg}$, zinc $12,000 \mathrm{mg}$, selenium $70 \mathrm{mg}$, vehicle $1,000 \mathrm{~g}$, vitamin A $12,000 \mathrm{UI}$, vitamin $\mathrm{D}_{3}$ $1,500 \mathrm{UI}$, vitamin E $50 \mathrm{mg}$, vitamin $\mathrm{K} 4 \mathrm{mg}$, vitamin $B_{12} 7 \mathrm{mg}$, vitamin $B_{2} 7 \mathrm{mg}$, pantotenic acid $60 \mathrm{mg}$, nicotinic acid $120 \mathrm{mg}$, coline chloride 600 $\mathrm{mg}$, metionin $700 \mathrm{mg}$, antioxidant $500 \mathrm{mg}$ and vehicle $1,000 \mathrm{~g}$. Mixed diets containing chromium were pelleted and stored in black bags at $-18^{\circ} \mathrm{C}$ until use. Fishes were fed once a day (9:00 h), ad libitum, for 90 days. Weekly, the aquatic characteristics as temperature, $\mathrm{pH}$, dissolved oxygen and electric conductivity were measured. Total ammonia was measured at each 15 days.

\section{Parasitological analysis}

After 7, 60 and 90 days, eight fishes of each treatment were separated by size, anestethized with benzocaine solution (50 mg. $\mathrm{l}^{-1}$ ), and their gills were removed for Monogenoidea and Dinoflagellate counts (Ghiraldelli et al. 2006). The results were treated by variance test $(\mathrm{P}<0.01)$, and Tukey test with $5 \%$ probability threshold was considered.

\section{RESULTS AND DISCUSSION}

The addition of chromium in the diet did not alter the water quality but significant difference $(\mathrm{P}<0.05)$ was observed when analysing the stocking densities $\left(4\right.$ and $\left.20 \mathrm{~kg} / \mathrm{m}^{3}\right)$ as shown in Table 1. Except for the temperature (constant 
during the experiment), high stocking density provoked worst water quality.The treatment with $20 \mathrm{~kg}$ of fishes $/ \mathrm{m}^{3}$ showed high concentration of ammonia and low levels of dissolved oxygen probably due to high feeding rate and fish excretion as suggested by Baskerville-Bridges and Kling (2000).

Table 1 - F values, variation coefficient (VC) and averages of aquatic characteristics of the aquaria with addition of chromium and different stocking densities (4 and $20 \mathrm{~kg}$ fish $\left./ \mathrm{m}^{3}\right)$. Temperature $\left(\mathrm{T}^{\circ} \mathrm{C}\right), \mathrm{pH}$, dissolved oxygen $\left(\mathrm{O}_{2} \mathrm{D}\right.$ $\mathrm{mg} / \mathrm{l})$, electric conductivity $(\mathrm{EC} \mu \mathrm{s} / \mathrm{cm})$ and total ammonia (TA $\mu \mathrm{g} / \mathrm{l})$.

\begin{tabular}{|c|c|c|c|c|c|}
\hline \multirow{2}{*}{ Statistic } & \multicolumn{4}{|c|}{ Variables } & \multirow[b]{2}{*}{ TA } \\
\hline & $\mathbf{T}$ & pH & $\mathrm{O}_{2} \mathbf{D}$ & EC & \\
\hline $\mathrm{F}$ to chromium levels $(\mathrm{Cr})$ & $1.16 \mathrm{~ns}^{*}$ & $0.59 \mathrm{~ns}$ & $0.88 \mathrm{~ns}$ & $0.99 \mathrm{~ns}$ & $0.01 \mathrm{~ns}$ \\
\hline F stocking densities ( $\mathrm{Sd}$ ) & $0.11 \mathrm{~ns}$ & $34.22 * *$ & $314.02 * *$ & $22.80 * *$ & $68.28 * *$ \\
\hline F interaction to CrxSd & $1.11 \mathrm{~ns}$ & $0.50 \mathrm{~ns}$ & $1.12 \mathrm{~ns}$ & $0.41 \mathrm{~ns}$ & $0.11 \mathrm{~ns}$ \\
\hline $\mathrm{VC}(\%)$ & 17.95 & 0.92 & 10.70 & 1.18 & 41.12 \\
\hline \multicolumn{6}{|c|}{ Averages for chromium levels } \\
\hline $0 \mathrm{mg} / \mathrm{kg}$ & 28.3 & 7.49 & 3.78 & 136.51 & 205.86 \\
\hline $6 \mathrm{mg} / \mathrm{kg}$ & 28.9 & 7.54 & 3.65 & 137.55 & 198.20 \\
\hline $12 \mathrm{mg} / \mathrm{kg}$ & 28.9 & 7.50 & 3.61 & 13782 & 197.20 \\
\hline $18 \mathrm{mg} / \mathrm{kg}$ & 32.7 & 7.51 & 3.90 & 137.48 & 196.60 \\
\hline \multicolumn{6}{|c|}{ Averages for stocking densitiy } \\
\hline $4 \mathrm{~kg}$ fish $/ \mathrm{m}^{3}$ & $30.0 \mathrm{a}$ & $7.58 \mathrm{a}$ & $4.99 \mathrm{a}$ & $138.71 \mathrm{a}$ & $61.11 \mathrm{a}$ \\
\hline $20 \mathrm{~kg}$ fish $/ \mathrm{m}^{3}$ & $29.4 \mathrm{a}$ & $7.44 \mathrm{~b}$ & $2.48 \mathrm{~b}$ & $135.97 \mathrm{~b}$ & $337.87 \mathrm{~b}$ \\
\hline
\end{tabular}

Different letters in the same column indicate significant difference by Tukey test $5 \%$.

After 7 days of experiment the fishes with more than $17 \mathrm{~cm}$ showed the highest number of $A$. penilabiatus in the gills. In spite of different length, the age of the fishes was the same, therefore, the immune system probably had the same development. Thus the higher number probably was due to higher area of gill surface for fixation of parasite (Table 2).

After 7 days of experiment, significant interaction was observed between chromium levels and stocking densities as the monogenoidea (Table 2). The fishes maintained at $4 \mathrm{~kg} / \mathrm{m}^{3}$ showed lower number of parasites $(\mathrm{P}<0.05)$ than those at 20 $\mathrm{kg} / \mathrm{m}^{3}$. Nevertheless, fishes fed 12 and $18 \mathrm{mg}$ $\mathrm{CQC} / \mathrm{kg}$ diet presented reduced number of $A$. penilabiatus in the first 7 days (Table 3). Apparently, there was the effect of chromium on fish parasite in the initial days of experiment. According to Hertz et al. (1989), the chromium is an essential mineral that acts in the glucose and lipid metabolism. Dietary supplementation with the chromium was proved to reduce the effects of stress in domestic animals (Mowat, 1997). In dairy cows supplementation of chromium caused insulin and cortisol release. As a result, the increased number of lymphocytes in vitro suggested its immunostimulant action (Chang et al., 1996). In different animal species, chromium may modulate the humoral and cellular factors by interacting with insulin and cortisol. Decreased cortisol concentration in chromium supplemented animals suggests its immune-endocrine modulation. It could be inferred that corticosteroids and insulin modulated the development of acute inflammatory reaction by antagonistic hormones. Elevated levels of corticosterone inhibit inflammation while insulin favours this phenomenon (Moraes and Garcia Leme, 1982). Thus, since chromium reduce cortisol in stressed animals, it will be less susceptible to infections by improving its immune system and inflammation.

In carp, the addition of $2 \mathrm{mg} \mathrm{CrCl} / 3 \mathrm{~kg}$ diet inhibit gluconeogenesis and improve the insulin action (Hertz et al., 1989). Increased utilization of glucose and improved growth was demonstrated in tilapia fed $2 \mathrm{mg} \mathrm{Cr}_{2} \mathrm{O}_{3} / \mathrm{kg}$ diet (Shiau and Chen, 1993). Moreover, the addition of $2 \mathrm{mg}$ chromium oxide $/ \mathrm{kg}$ diet of the hybrid tilapia enhanced the fish weight gain, energy stocks and hepatic glycogen probably due insulin action (Shiau and Lin. 1993). 
In the second fish collection (60 days), the fishes maintained at $20 \mathrm{~kg} / \mathrm{m}^{3}$ showed higher number of monogenoidea parasite $(\mathrm{P}<0.05)$ than those at 4 $\mathrm{kg} / \mathrm{m}^{3}$. $(\mathrm{P}<0,05) \quad($ Table 2$)$. The high stocking density is one of the most common stressor in aquaculture that determines the competition between the animals and decreased utilization of food nutrients (Papoutsoglou et al., 1998). Anderson (1994) reported enhanced fish excretion during the stress and rise demand for minerals. The elevated excretion and poor utilization of food provoke low water quality, reduced growth and diminish the immunological response (Baskerville-Bridges and Kling, 2000; Montero et al., 1999). This phenomenon might have occurred in this work with pacu since fishes of present work maintained at high stocking density with low water quality presented higher number of parasites.
Analysing the Table 3, the fishes fed with chromium supplementation showed decreased $P$. pillulare number in both densities, but in the 4 $\mathrm{kg} / \mathrm{m}^{3}$ no statistical differences was observed. In the density of $20 \mathrm{~kg} / \mathrm{m}^{3}$ and fishes supplemented from $6 \mathrm{mg} / \mathrm{kg}$ of diet, lower number of dinoflagellate was observed.

The time of experiment also influenced the average number of the parasite. Decreased number was observed after 60 days and increased after 90 days (Table 2). This occurred probably due to worsening water quality during the experiment. Fishes maintained at $20 \mathrm{~kg} / \mathrm{m}^{3}$ without chromium supplementation showed higher number of $P$. pillulare than the fishes maintained at low density, but no significant difference was observed (Table $3)$.

Table 2 - F values, variation coefficient (VC) and average number of Anacanthorus penilabiatus (7, 60 and 90 days) and Piscinoodinium pillulare in the gills of Piaractus mesopotamicus maintained in two stocking densities and supplemented with chromium.

\begin{tabular}{|c|c|c|c|c|}
\hline \multirow[t]{2}{*}{ Statistic } & \multicolumn{4}{|c|}{ Average number of parasites* } \\
\hline & 7 days & 60 days & 90 days & Piscinoodinium \\
\hline $\mathrm{F}$ to chromium levels $(\mathrm{Cr})$ & $4.93 * *$ & $0.43 \mathrm{~ns}$ & $0.50 \mathrm{~ns}$ & $9.58 * *$ \\
\hline F to stocking $(\mathrm{Sd})$ & $637.97 * *$ & $14.06^{* *}$ & $1.57 \mathrm{~ns}$ & $0.14 \mathrm{~ns}$ \\
\hline $\begin{array}{l}\mathrm{F} \text { to length (Lt-monogenea) or } \mathrm{F} \text { to } \\
\text { Periods (Pr-Piscinoodinium) }\end{array}$ & $9.15 * *$ & $0.05 \mathrm{~ns}$ & $0.75 \mathrm{~ns}$ & $20.33 * *$ \\
\hline F interaction to $\mathrm{CrxSd}$ & $6.51 * *$ & $0.43 \mathrm{~ns}$ & $0.67 \mathrm{~ns}$ & $2.76^{*}$ \\
\hline $\mathrm{F}$ interaction to $\mathrm{CrxLt}$ & $2.20 \mathrm{~ns}$ & $0.54 \mathrm{~ns}$ & $0.79 \mathrm{~ns}$ & $0.79 \mathrm{~ns}$ \\
\hline F interaction to $\mathrm{SdxLt}$ & $0.71 \mathrm{~ns}$ & $0.53 \mathrm{~ns}$ & $2.55 \mathrm{~s}$ & $2.89 \mathrm{~ns}$ \\
\hline $\mathrm{CV}(\%)$ & 19.31 & 18.83 & 18.88 & 15.22 \\
\hline \multicolumn{5}{|c|}{ Averages for chromium levels } \\
\hline $0 \mathrm{mg} / \mathrm{kg}$ de ração & 60.48 & 85.73 & 90.00 & 9.19 \\
\hline $6 \mathrm{mg} / \mathrm{kg}$ de ração & 52.42 & 79.44 & 87.41 & 7.67 \\
\hline $12 \mathrm{mg} / \mathrm{kg}$ de ração & 49.84 & 82.64 & 84.62 & 7.89 \\
\hline $18 \mathrm{mg} / \mathrm{kg}$ de ração & 47.52 & 82.97 & 82.58 & 7.82 \\
\hline \multicolumn{5}{|c|}{ Averages for stocking densitiy } \\
\hline $4 \mathrm{~kg}$ de peixes $/ \mathrm{m}^{3}$ & 20.53 & $75.39 \mathrm{~b}$ & 85.54 & 8.10 \\
\hline $20 \mathrm{~kg}$ de peixe $/ \mathrm{m}^{3}$ & 84.50 & $90.00 \mathrm{a}$ & 89.86 & 8.18 \\
\hline \multicolumn{5}{|c|}{ Averages for length } \\
\hline Below of $17 \mathrm{~cm}$ & $48.72 \mathrm{a}$ & 82.24 & 84.89 & $\mathrm{X}$ \\
\hline Up to $17 \mathrm{~cm}$ & $56.41 \mathrm{~b}$ & 83.14 & 87.31 & $\mathrm{X}$ \\
\hline \multicolumn{5}{|c|}{ Averages for period } \\
\hline 7 days & $\mathrm{X}$ & $\mathrm{X}$ & $\mathrm{X}$ & $8.79 \mathrm{~b}$ \\
\hline 60 days & $\mathrm{X}$ & $\mathrm{X}$ & $\mathrm{X}$ & $7.13 \mathrm{a}$ \\
\hline 90 days & $\mathrm{X}$ & $\mathrm{X}$ & $\mathrm{X}$ & $8.50 \mathrm{~b}$ \\
\hline
\end{tabular}

Different letters in the same column indicate significant difference by Tukey test $(\mathrm{P}<0.05)$. Averages were transformed in alog $(\mathrm{x}+0.5)$. 
Table 3 - Effects of chromium interaction (Cr) and stocking densities on the average number of Anacanthorus penilabiatus after 7 days of feeding and Piscinoodinium pillulare in the gills of Piaractus mesopotamicus

\begin{tabular}{lcccc}
\hline Chromium levels & \multicolumn{2}{c}{ Anacanthorus penilabiatus } & \multicolumn{2}{c}{ Piscinoodinium pillulare } \\
\cline { 2 - 4 } & $4 \mathrm{~kg} / \mathrm{m}^{3}$ & $20 \mathrm{~kg} / \mathrm{m}^{3}$ & $4 \mathrm{~kg} / \mathrm{m}^{3}$ & $20 \mathrm{~kg} / \mathrm{m}^{3}$ \\
\hline $0 \mathrm{mg} / \mathrm{kg}$ & $27.8 \mathrm{Ba}$ & $277.6 \mathrm{Ab}$ & $9,407 \mathrm{Aa}$ & $18,218 \mathrm{Ba}$ \\
$6 \mathrm{mg} / \mathrm{kg}$ & $7.5 \mathrm{Ba}$ & $197.8 \mathrm{Ab}$ & $3,819 \mathrm{Aa}$ & $4,999 \mathrm{Aa}$ \\
$12 \mathrm{mg} / \mathrm{kg}$ & $3.5 \mathrm{Aa}$ & $240.3 \mathrm{Ab}$ & $3,541 \mathrm{Aa}$ & $6,061 \mathrm{Aa}$ \\
$18 \mathrm{mg} / \mathrm{kg}$ & $6.6 \mathrm{Aa}$ & $152.1 \mathrm{Ab}$ & $3,949 \mathrm{Aa}$ & $3,899 \mathrm{Aa}$ \\
\hline
\end{tabular}

Capital letters indicate significant difference between chromium levels and minuscule letters indicate significant difference between stocking densities.

The number of parasites in the fishes is directly related to low dissolved oxygen, high organic matter contents and overcrowding, as suposted by Martins et al. (2002) and Moraes and Martins (2004). In São Paulo State- Brazil, from cases of fishes diagnosed with parasite $P$. pillulare, $73.3 \%$ occurred in the cold season with temperatures of 17 to $24^{\circ} \mathrm{C}$, and the hybrid tambacu (Colossoma macropomum female x $P$. mesopotamicus male) was the most susceptible fish followed by $P$. mesopotamicus, C. macropomum, Leporinus macrocephalus and Oreochromis niloticus (Moraes and Martins, 2004). These supported the presents results when water quality were reduced due to overcrowding. The fishes not supplemented and maintained in high stocking density showed higher parasitism index than supplemented ones, as shown in Table 3. In stress condition, high cortisol levels are responsible for lost glucose sensibility (Borgs and Mallard, 1998). The reduced levels of cortisol (Anderson, 1994; Committee on Animal Nutrition, 1997), increased action of insulin (Anderson, 1981, Schwatrz and Mertz cited by Mordenti et al., 1997) and/or immustimulant effect (Anderson, 1994) provoked by chromium supplementation possibly might have reduced the number of $P$. pillulare. The results suggested that the fishes stressed by stocking density might have improved their health with the addition of up to $6 \mathrm{mg} \mathrm{CQC} / \mathrm{kg}$ diet. According to Anderson (1994), stressed fishes have more exigency of dietary mineral since the stress was responsible for alteration of mineral and vitamin requirement (Anderson, 1994; Committee on Animal Nutrition, 1997).

However, the mechanisms of chromium action in the fishes are unknown. In conclusion, it was possible that chromium supplementation $(12 \mathrm{mg}$ $\mathrm{CQC} / \mathrm{kg}$ ) favoured the good health of the fishes as prophylaxis measure by reducing Monogenoidea and Dinoflagellida number in lower densities and the level of $18 \mathrm{mg} / \mathrm{kg}$ in the higher densities.

\section{RESUMO}

O objetivo do trabalho foi avaliar a intensidade de parasitismo por monogenóide Anacanthorus penilabiatus e pelo dinoflagelado Piscinoodinium pillulare em pacus Piaractus mesopotamicus, cuja dieta foi suplementada com cromo. Foram utilizados dois delineamentos em esquema fatorial, consistindo de 4 níveis de cromo $(0,6,12,18$ $\mathrm{mgCQC} / \mathrm{kg}$ ), duas densidades de estocagem (4 $\mathrm{kg} / \mathrm{m}^{3}$ e $20 \mathrm{~kg} / \mathrm{m}^{3}$ ) e duas classes de tamanho para monogenóide (maiores e menores de $17 \mathrm{~cm}$ ) e/ou 3 períodos de coleta (7, 60 e 90 dias), com quatro repetições. Os peixes que receberam 12 e $18 \mathrm{mg}$ $\mathrm{CQC} / \mathrm{kg}$ apresentaram diminuição de monogenóides após 7 dias de alimentação na menor densidade. Nos peixes na maior densidade, os níveis de 6, 12 e $18 \mathrm{mgCQC} / \mathrm{kg}$ ocasionou redução de dinoflagelados. Os resultados demonstraram que a suplementação com cromo (12 e $18 \mathrm{mgCQC} / \mathrm{kg}$ ) promoveu uma melhora na saúde dos peixes na menor e na maior densidade, respectivamente.

\section{REFERENCES}

A.O.A.C. Association of official agricultural chemists. (1984), Washington. Official methods of analysis of the Association of Official Agricultural Chemists. Washington. 1141pp.

Alkahem, H.F. (1994), The toxicity of nickel and the effects of sublethal levels on haematological parameters and behaviour of the fish, Oreochromis niloticus. Journal of University of Kwait Science. 21(2), 243.252.

Anderson, R.A. (1994), Stress effects on chromium nutrition of humans and farmal animals. In: Biotechnology in the Feed Industry.10, pp.267.73

Anderson, R.A. (1981), Nutriotional role of chromium. The Science of the Total Environment. 17, 13.29. 
Barton, B.A., Iwama, G.W. (1991), Physiological changes in fish from stress in aquaculture with emphasis on the response and effects of corticosteroids. Annual Review on Fish Diseases. 1, 3.26 .

Baskerville-Bridges, B., Kling, L. J. (2000), Larval culture of atlantic cod (Gadus morhua) at high stocking densities. Aquaculture. 181, 61.9.

Belo, M.A.A. (2002), Efeito do estresse e da suplementação alimentar com vitamina E sobre a formação de gigantócitos em lamínulas de vidro implantadas no tecido subcutâneo de Piaractus mesopotamicus (Holmberg, 1887). Dissertação (Mestrado em Medicina Veterinária) - Faculdade de Ciências Agrárias e Veterinárias, Unesp, Jaboticabal, SP.

Böeger, W.A., Husak, W.S.; Martins, M.L. (1995), Neotropical Monogenoidea. 25. Anacanthorus penilabiatus n.sp. (Dactylogyridae: Anacanthorinae) from Piaractus mesopotamicus (Holmberg, 1887). cultivated in the State of São Paulo, Brazil. Memórias Instituto Oswaldo Cruz. 90, 699.701.

Borgs, P., Mallard, B.A. (1998), Immune-endocrine interactions in agricultural species: chromium and its effect on health and performance. Domestic Animal Endocrinology. 15(5), 431.438.

Brum, C. (2003), A vitamina C favorece a formação de macrófagos policariontes em Piaractus mesopotamiocus (Holmberg, 1887). mantidos em diferentes densidades. Dissertação (Mestrado em Aqüicultura) - Centro de Aqüicultura da Unesp, Jaboticabal, SP, 58.

Camacho, R.D. (1999), Estresse e apetite na tilápia do nilo. Dissertação (Mestrado, Instituto de Biologia) UNESP, Botucatu, SP.

Chang, X., Mallard, B.A., Mowat, D.N. (1996), Effects of chromium on health status, blood neutrophil phagocytosis and in vitro lymphocyte blastogenesis of dairy cows. Veterinary Immunology and Immunopathology. 52, 37.52.

Comittee on Animal Nutrition. Academy Press, (1997), The Role Of Chromium In Animal Nutrition, 79 pp.

Ghiraldelli 1.; Martins M.L.; Jerônimo G.T.; Yamashita M.M.; Adamante W.B. (2006), Ectoparasites communities from Oreochromis niloticus cultivated in the State of Santa Catarina, Brazil. Journal of Fisheries and Aquatic Sciences 1 (2), 181-190

Hasten, D.L., Hegsted, M., Keenan, M.J., Morris, G.S. (1997), Effects of various forms of dietary chromium on growth and body composition in the rat. Nutrition Research. 17(2), 283.294.

Hertz, Y., Madar, Z., Hepher, B., Gertler, A. (1989), Glucose metabolism in the common carp (Cyprinus carpio): the effects of cobalt and chromium. Aquaculture. 76, 255.267.
Hossain S, M., Barreto, S.B., Silva, C.G. (1998), Growth performance and carcass composition of broilers fed supplemental chromium from chromium yeast. Animal Feed Science Technology. 71, 217.228.

Kritsky, D.C.; Boeger, W.A.; Jégu, M. (1997), Neotropical Monogenea. 29. Ancyrocephalinae (Dactylogyridae) of piranha and their relatives (Teleostei, Serrasamidae) from Brazil: Species of Anphitecium Boeger and Kitsky, 1988, Heterothecium gen. N. and Phitanothecium gen. N. Journal of Helmintological Society of Washington. 64, 25.54.

Martins, M.L., Moraes, J.R.E., Andrade, P.M., Schalch, S.H.C., Moraes, F.R. (2001), Piscinoodinium pillulare (Schaperclaus, 1954) Lom, 1981 (Dinofagellida) infection in cultivated freswater fish from northeast region of São Paulo state, Brazil. Parasitological and pathological aspects. Revista Brasileira de Biologia. 61, 1.6.

Martins, M.L., Onaka E.M., Moraes F.R., Bozzo F.R., Paiva A.M.F.C. and Gonçalves A. (2002), Recent studies on parasitic infections of freshwater cultivated fish in the State of São Paulo, Brazil. Acta Scientiarum. 24(4), 981.985.

Maule, A.G.; Tripp, R.A.; Kaattari, S.L.; Schreck, C.B. (1989), Stress alters the immune function and disease resistence in chinook salmon Oncorhynchus tshawytscha. Journal of Endocrinology. 120, 135.142.

Mazeaud, M.M.; Mazeaud, F. (1981), Adrenergic response to stress in fish. In: Pickering, A.D. Stress and Fish. Academic Press, pp. 49.75.

Montero, D.; Marrero, M.; Izquierdo, M.S.; Robaina, L.; Vergara, J.M.; Tort, L. (1999), Effect of vitamin E and $\mathrm{C}$ dietary supplementation on some immune parameters of gilthead seabream (Sparus aurata) juveniles subjected to crowding stress. Aquaculture. 171, 269.278.

Moraes, F.R.; Garcia leme, J. (1982), Endogenous corticosteroids and insulin in acute inflammation. Microvascular Research. 23, 281.283.

Moraes, F.R.; Martins, M.L. (2004), Condições predisponentes e principais enfermidades de teleósteos cultivados. In: Tópicos especiais em piscicultura de água doce tropical intensiva. Cyrino et al. São Paulo. TecArt, pp.343.387.

Mordenti, A.; Piva, A.; Piva, G. (1997), The european pesrspective on organic chromium in animal nutrition. In: Biothecnology in the Feed Industry, 13, pp.227.239.

Mowat, D.N. (1997), Organic chromium in animal nutrition. Chromium books, Guelph, Ontario, 258 pp. Papoutsoglou, S.E., Tziha, G., Vrettos, X., Athanasiou, A. (1998), Effects of stocking density on behaviour and growth rate of European sea bass (Dicentrarchus labrax) juveniles reared in a closed circulated system. Aquacultural Engineering. 18,135.144. 
Pickering, A.D., Pottinger, T.G. (1985), Cortisol can increase the susceptibility of brown trout, Salmo trutta, to disease without reducing the white blood cell count. Journal of Fish Biology. 27, 611.119.

Rhode, K. (1993), Ecology of marine parasites. CAB International, Wallingford, U.K., 298pp.

Rotlland, J., Pavlidis, M., Kentouri, M., Abad, M.E., Tort, L. (1997), Non-specific immune reponses in the red progy pagrus pagrus after crowding stress. Aquaculture, 156, 279.90.

Shiau, S., Chen, M. (1993), Carbohydrate utilization by tilapia (O. niloticus X O. aureus) as influenced by different chromium sources. Nutrient Requeriments and Interactions, 1, 1747.53.

Shiau, S., Lin, S. (1993), Effect of suplemental dietary chromium and vanadium on the utilization of diferent carbohydrates in tilapia, O. niloticus X O. aureus. Aquaculture. 110, 321.330.

Thatcher, V.E.; Brites-Neto, J. (1994), Diagnóstico, prevenção e tratamento das enfermidades de peixes neotropicais de água doce. Revista Brasileira de Medicina Veterinária. 16(3), 111.128.
Tort, L., Sunyer, J.O., Gomez, E., Molinero, A. (1996), Crowding stress induces changes in serum haemolytic and agglutinating activity in the gilthead sea bream (Sparus aurata). Veterinary and immunology and Immunopathology. 51, 179.188.

Wedemeyer, G.A. (1997), Effects of rearing conditions on the health and physiological quality of fish in intensive culture. In: Iwama, G.K.; Pickering, A.D.; Sumpter, J.P.; Schreck, C.B. Fish Stress and Health in Aquaculture. pp. 35.71.

Yadav, J.; Akela, B.P. (1993), Aldrin induced haematological changes on the common indian catfish, Clarias batrachus (Linn). Comparative Biochemistry and Physiology. 18(4), 156.159. 